\title{
Evaluation of Fall Burning on Bighorn Sheep Winter Range
}

\author{
JAMES M. PEEK, ROBERT A. RIGGS, AND JERRY L. LAUER
}

\begin{abstract}
Bighorn sheep and mule deer grazed bluebunch wheatgrass on areas on a Wyoming big sagebrush/bluebunch wheatgrass winter range significantly greater than adjacent unburned sites for 4 years after burning. Grass production decreased slightly the first year after burning but returned to preburn levels 2 years afterwards. Frequency of bluebunch wheatgrass in plots was reduced for 2 years following burning but returned to preburn levels by the third year. Big sagebrush seedlings were noted on burned sites 2 years after burning. Burning was considered to benefit bighorn more than mule deer because sagebrush, an important component of the mule deer diet, was effectively removed from the site for at least 4 years after burning.
\end{abstract}

Many populations of bighorn sheep (Ovis canadensis) occur as small, isolated bands in the upper Salmon River area of Idaho. Restoration of bighorn sheep winter range is one aspect of increasing these populations to levels which ensure that local extinction will not occur, and hopefully to levels which will eventually provide regulated sport hunting.

These populations occupy Wyoming big sagebrush (Artemisia tridentata wyomingensis)-bluebunch wheatgrass (Agropyron spicatum) rangelands that offer opportunities to enhance productivity through prescribed burning, which would hopefully favor the preferred grass forage and decrease the sagebrush. In addition, these winter ranges are used by mule deer (Odocoileus hemionus), which prefer sagebrush and other browse species (Lauer and Peek 1976). As the preferred deer forage species are reduced by burning, and bighorn forage species are favored, deer use may be reduced on these sites, which would lessen competition with bighorn. This paper describes responses of vegetation and ungulate use on seven small burns conducted in September 1974 on the East Fork Salmon River bighorn sheep winter range.

\section{Study Area and Methods}

The East Fork Salmon River winter range is located approximately $20 \mathrm{~km}$ south of the confluence of the East Fork with the main Salmon River in east-central Idaho. It is approximately $86 \mathrm{~km}^{2}$, with elevations ranging from $1,744-2,438 \mathrm{~m}$. Soils are derived from Challis Volcanics, composed chiefly of andesite flows and flow breccias (Ross and Savage 1967). Mean annual temperature at Challis, Idaho, $34 \mathrm{~km}$ north, is $7^{\circ} \mathrm{C}$, and annual precipitation averages $18 \mathrm{~cm}$,

\footnotetext{
Authors are professor and research associates, College of Forestry, Wildlife and Range Sciences, University of Idaho, Moscow. Lauer is now a wildlife biologist for the Bureau of Indian Affairs, Pendleton, Oregon.

Authors thank Craig T. Kvale, Jeffrey J. Yeo for assistance in data collection. Loren Anderson and Jerry Christian, Bureau of Land Management, Salmon, Idaho, and Lanny $\mathrm{O}$. Wilson, Bureau of Land Management, Boise, organized and conducted the burning. This report was financed by McIntire-Stennis Project MS-22, the Forest Wildlife and Range Experiment Station, University of Idaho, Idaho Cooperative Wildlife Research Unit, William T. Wittinger and, the Bureau of Land Management. Paper No. 150, Forest, Wildlife, and Range Experiment Station, University of Idaho.

much occurring as rain in May and June. Snowpack rarely exceeds 15 $\mathrm{cm}$ at lower elevations, but may exceed $61 \mathrm{~cm}$ at higher elevations. Precipitation at Challis, $34 \mathrm{~km}$ north of the study area, was lower than normal in spring (April, May, and June) but higher than normal in fall (September-October) from 1975-1977. Fall precipitation was $177 \%$ of normal in 1975, 219\% in 1976, and $125 \%$ in 1977. Total precipitation from 1974-1977 ranged from 93-128\% of normal.

Seven areas ranging in size from 0.05 to 0.45 ha and totaling 1.51 ha were burned in September 1974, using hand-held propane torches and flares. Small patches of unburned vegetation within the fire perimeter were burned later. Unburned stubble less than $5 \mathrm{~cm}$ tall was present on most bluebunch wheatgrass plants after burning. Wyoming big sagebrush plants were completely burned, with a few stems burned to below-ground level. No fall regrowth occurred after the burning.

Vegetation analysis consisted of evaluation of composition and vigor of bluebunch wheatgrass on each of the seven sites. Permanently marked 15:2-m transects were established, and twenty $2 \times 5-\mathrm{dm}$ plots were located at $1.5-\mathrm{m}$ intervals. Ground cover was determined by recording live vegetation, litter, and inorganic material at the four corner points of each plot. Frequency of occurrence of each species within the 20 plots was obtained. Production of grasses, forbs, and shrubs was obtained in July by clipping ten $2 \times 5$-dm plots on the burned and unburned sites. Grazed and ungrazed heights of vegetative growth of 100 burned and unburned bluebunch wheatgrass plants were measured in spring of each year. Percentage grazed of 100 randomly selected bluebunch wheatgrass plants was also obtained on burned and adjacent unburned sites. Analyses of variance and Duncan's multiple range tests to determine significant differences in means of observed parameters between years on burned and unburned sites were used to evaluate the data. Pearson correlation coefficients were used to determine rclationships between precipitation and vegetation production. All information except utilization data were collected until no differences attributable to burning occurred or trends could be established.

\section{Results}

\section{Changes in Vegetation}

Total ground cover combined did not change from preburn levels until the fourth year after burning, when a significant increase occurred (Table 1). Live vegetation cover was reduced

Table 1. Changes in live vegetation, litter, and total ground coverage before burning and for 2 years afterwards in bighorn sheep winter range, East Fork Salmon River, Idaho. Data are percentages. of $20 \times 5 \mathrm{dm}$ plot-frame corner-point hits, with 560 points ( 80 per site) per year.

\begin{tabular}{lccc}
\hline Year & $\begin{array}{c}\text { Live } \\
\text { vegetation }\end{array}$ & Litter & $\begin{array}{c}\text { Total ground } \\
\text { cover }\end{array}$ \\
\hline Preburn 1974 & $6.5^{a b 1}$ & $19.1^{a b}$ & $25.6^{a}$ \\
Postburn 1975 & $4.0^{a}$ & $15.1^{a b}$ & $19.1^{a}$ \\
Postburn 1976 & $9.4^{a b}$ & $16.9^{a b}$ & $26.3^{a}$ \\
Postburn 1977 & $12.0^{c b}$ & $12.3^{b}$ & $24.3^{a}$ \\
Postburn 1978 & $16.4^{c}$ & $26.1^{a}$ & $42.5^{b}$ \\
\hline
\end{tabular}

${ }^{1}$ Unlike superscripted letters indicate significant differences between years at $\propto=.05$. 
Table 2. Frequency of occurrence (F) and canopy cover (cc) of big sagebrush, frequency of occurrence and basal area (ba) of bluebunch wheatgrass and annual forbs before and after burning on bighorn sheep winter range, East Fork Salmon River, Idaho.

\begin{tabular}{|c|c|c|c|c|c|c|c|c|}
\hline & \multicolumn{2}{|c|}{ Preburn 1974} & \multicolumn{2}{|c|}{ Postburn 1975} & \multicolumn{2}{|c|}{ Postburn 1976} & \multicolumn{2}{|c|}{ Postburn 1977} \\
\hline & $\mathrm{ba} / \mathrm{cc}$ & $\mathrm{F}$ & $\mathrm{ba} / \mathrm{cc}$ & $\mathrm{F}$ & $\mathrm{ba} / \mathrm{cc}$ & $\mathrm{F}$ & $\mathrm{ba} / \mathrm{cc}$ & $\mathrm{F}$ \\
\hline Artemesia tridentata & $14.8^{a_{1}}$ & $47.9^{a}$ & $2.6^{b}$ & $7.9^{b}$ & $2.0^{b}$ & $6.4^{b}$ & $2.8^{b}$ & $5.7^{b}$ \\
\hline Agropyron spicatum & $2.2^{a}$ & $75.7^{a}$ & $3.1^{a}$ & $53.6^{D}$ & $2.0^{a}$ & $47.1^{\circ}$ & $2.8^{a}$ & $67.0^{a}$ \\
\hline Annual forbs & $0.0^{b}$ & $0.0^{b}$ & $0.07^{b}$ & $8.6^{b}$ & $0.87^{a}$ & $28.6^{a}$ & $0.01^{b}$ & $0.0^{b}$ \\
\hline
\end{tabular}

1 Unlike letters indicate significant differences at $\propto=0.05$. All data are expressed in percentages.

slightly the year following burning but showed a significant trend upwards thereafter. Cover of live vegetation was significantly higher than before burning by the fourth growing season after the burn. Litter cover did not show clear trends throughout the 5-year study period, and was sparsely distributed on these sites.

Big sagebrush decreased significantly following burning but did not change in canopy cover or frequency thereafter (Table 2). Big sagebrush seedlings appeared on burned sites two growing seasons after the fire. Other shrubs, including rubber rabbitbrush (Chrysothamnus viscidiflorus), fleabane (Erigeron filifolius), eriogonum (Eriogonum microthecum), Leptodactylon (Leptodactylon pungens), Hood's phlox (Phlox hoodii), and squaw currant (Ribes cereum), occurred in less than $5 \%$ of plots on burns and were too sparse to show trends from the data. Squaw currant was resprouting on burned sites not sampled, however. All woody species except big sagebrush were present in low amounts before and after burning, with no apparent change in frequency while canopy coverage was too low to provide comparisons.

Perennial forbs did not show changes attributable to burning, with total basal area and frequency never reaching above $0.1 \%$ and $5 \%$, respectively, for any site. Forbs were dormant by the time species composition was determined (mid-July), but even during the spring growing period they were very sparse on these dry slopes. Major forb species included lupines (Lupinus spp.), milk vetch (Astragalus spp.), and hawksbeard (Crepis acuminata). Annual forbs increased significantly 2 years after burning, but no differences were apparent between preburn, year following burning, or the third year after burning. Frequency of annual forbs was correlated with fall precipitation $\left(R^{2}=87\right)$, but not spring precipitation $\left(R^{2}=.17\right)$.

No significant changes in basal area of bluebunch wheatgrass occurred, suggesting that some smaller plants were killed. In spring 1975, bluebunch wheatgrass initiated growth 7-14 days earlier on burned areas than on adjacent unburned sites, but by the time flowering occurred no differences were apparent. Other grass species, including Indian ricegrass (Oryzopsis hymenoides) and Sandberg bluegrass (Poa sandbergii), were present in low amounts and did not evidence trends related to burning.

Grass production decreased slightly following burning although the difference was not significant (Table 3). Two and three years later, production was significantly higher than in the first year. Production the second and third year after burning

Table 3. Production of grasses, forbs, and shrubs $\left(\mathrm{gm} / \mathrm{m}^{2}\right)$ before and after burning on bighorn sheep winter range, East Fork Salmon River, Idaho.

\begin{tabular}{lcllc}
\hline & Grasses & Forbs & Shrubs & Total \\
\hline Preburn 1974 & $12.9^{a b 1}$ & $0.0^{b}$ & $6.2^{a}$ & $19.2^{a b}$ \\
Postburn 1975 & $9.5^{a}$ & $0.5^{a b}$ & $0.0^{b}$ & $9.8^{b}$ \\
Postburn 1976 & $29.9^{b}$ & $3.3^{a}$ & $0.6^{b}$ & $24.8^{a}$ \\
Postburn 1977 & $18.5^{b}$ & $1.2^{a b}$ & $0.3^{b}$ & $19.7^{a b}$ \\
\hline
\end{tabular}

${ }^{1}$ Unlike letters indicate significant differences between years at $x=.05$. was higher than on the preburn, but differences were not significant. No correlation with precipitation was apparent.

Forb production was greater the second year after burning, than for the other 3 years, including the preburn production. This was again significantly correlated with fall precipitation $\left(R^{2}=.90\right)$, but not spring precipitation $\left(R^{2}=.37\right)$. Shrubs were significantly reduced after burning, with Wyoming big sagebrush being the most important species affected.

Total production followed trends similar to the grass component with a significant decrease the year following burning and a return to preburn levels by the second and third years.

\section{Utilization}

Ungrazed heights of bluebunch wheatgrass were significantly lower on burned sites the second and third year after burning, but not by the fourth (Table 4). Grazed heights showed similar

Table 4. Comparisons of $\%$ bluebunch wheatgrass plants grazed, ungrazed and grazed stubble heights on burned and unburned sites on bighorn sheep winter range, East Fork Salmon River, Idaho. One hundred plants were sampled on each site.

\begin{tabular}{|c|c|c|c|c|c|c|}
\hline & \multirow{2}{*}{$\begin{array}{c}\% \\
\text { grazed } \\
\text { on } \\
\text { burn }\end{array}$} & \multirow{2}{*}{$\begin{array}{c}\% \\
\text { grazed } \\
\text { on } \\
\text { unburned }\end{array}$} & \multicolumn{2}{|c|}{$\begin{array}{c}\text { Cm } \\
\text { Ungrazed } \\
\text { heights }\end{array}$} & \multicolumn{2}{|c|}{$\begin{array}{c}\mathrm{Cm} \\
\text { Grazed } \\
\text { heights }\end{array}$} \\
\hline & & & Burn & Unburned & Burn & Unburned \\
\hline $1975^{1}$ & 73.3 & 7.6 & - & - & - & - \\
\hline 1976 & 66.0 & 25.0 & 27.7 & 29.0 & 10.1 & 11.0 \\
\hline 1977 & 30.3 & 10.1 & 27.7 & 28.2 & 10.5 & 11.1 \\
\hline 1978 & 35.6 & 22.0 & 28.4 & 28.8 & 13.9 & 13.7 \\
\hline
\end{tabular}

' No height data taken first growing season following burning.

trends. Utilization was consistently higher on burned sites throughout the period, and was greater the first 2 years after burning than later, with the comparison being significant.

\section{Discussion}

Similar delayed, positive responses in bluebunch wheatgrass to burning have been noted by Harniss and Murray (1973), Conrad and Poulton (1966), and Mueggler and Blaisdell (1958). Lack of an apparent response by Poa sandbergii, is similar to that found by Wright and Klemmedson (1965). Examination of a Wyoming big sagebrush site burned in July 1960 near the mouth of the East Fork Salmon River revealed little reestablishment of sage after 15 years, whereas Harniss and Murray (1973) showed increases in mountain big sage (Artemisia tridentata vaseyana) 12 years after burning, and extensive increases in green rabbitbrush 3 years after burning. Since other shrub species are so sparse on these sites, ground cover is low, and sites are small, big sage should reinvade more rapidly than on the 1960 burned area.

Daubenmire's (1968) review suggested that most published data reveal increases in nutrient content of grasses appearing after a fire, which makes them more attractive to grazing 
animals. However, the initial increase in nutrients is shortlived, often lasting only 1 year (Pearson et al. 1972) and some work suggests no change (Merrill 1978). Thus, the continued high use of burned sites may be related initially to increases in nutrient content, but the continued use is not. Adjacent unburned plants had accumulated much dead material, which was not removed by grazing, while the burned sites were grazed heavily enough to prevent accumulations of dead material. The small size of each area may have prolonged the effect of burning by allowing animals to concentrate use on them. Lower ungrazed seed stalk heights in 1976 and 1977 on burned sites may reflect the heavier grazing pressure than on unburned sites.

Unfortunately, we could not positively distinguish between mule deer and bighorn sheep use on these burns. Differences in pellet $\mathrm{pH}$ proved to be insignificant, (Peek and Keay 1979) and visual differences in pellets and tracks between the two species were not considered to be reliable enough to use in separation. However, we believe that most winter use on bluebunch wheatgrass was made by bighorn rather than mule deer. Bedding sites characteristic of bighorns were frequently observed. The percentages of bluebunch wheatgrass in the December 1974-May 1975 diets of bighorn in this vegetative type averaged $62 \%$, as compared to $30 \%$ for mule deer (Lauer and Peek 1976), with most of the use by mule deer occurring on new growth in spring. Use of dried seed heads and vegetative growth was attributable primarily to bighorns.

Nevertheless, for 4 years after the burn, utilization of bluebunch wheatgrass was greater on burned sites than on adjacent unburned sites. This use remained higher after grass production, predominantly bluebunch wheatgrass, had leveled off. This implies than an interval of between 5 and 10 years between prescribed burns may be appropriate to enhance forage condition.

Bighorn sheep have been associated with stable, long-lasting climax grass communities (Geist 1971:125), and the winter range of this population may be considered as a climax shrub-grass steppe, consonant with this concept. As a result, bighorn have been considered by Nelson (1976) as being adversely affected by fire in their habitat. Additionally, bighorn are often associated with wilderness conditions (Schoenfeld and Hendee 1978), which implies to some that opportunities for habitat management are indeed limited.

Nevertheless, fire can be a useful tool in bighorn habitat management in two ways: (1) it may retard successional advance of seral grassland towards conifer climax (Stelfox $1971,1976)$ and (2) it may improve production and palatability of important forage species. We are satisfied that the latter was occurring on the study area.

This investigation serves to demonstrate the potential of prescribed fire as a tool in bighorn sheep habitat management. However, we believe that demonstrations of improvement in habitat conditions and increases in utilization by bighorn are only initial steps. Evaluation of fire management for bighorn sheep will ultimately have to include estimates of survival and population trend which can be correlated with fire-induced habitat change. Such evaluations will have to be made on areas treated with fire which are much larger than these, over a longer time span.

\section{Literature Cited}

Conrad, E., and C.E. Poulton. 1966. Effect of a wildfire on Idaho Fescue and bluebunch wheatgrass. J. Range Manage. 19:138-141.

Daubenmire, R. 1968. Ecology of fire in grasslands. In: J.B. Cragg, ed. Advances in Ecological Research. Vol. 5. Academic Press, NY, p. 209-266.

Geist, V. 1971. Mountain Sheep: A Study in Behavior and Evolution. Univ. of Chicago, Press, Chicago. 383 p.

Harniss, R.O., and R.B. Murray, 1973. 30 years of vegetal change following burning of sagebrush-grass range. J. Range Manage. 26:322-325.

Lauer, J.L., and J.M. Peek. 1976. Big game livestock relationships on the bighorn sheep winter range East Fork Salmon River, Idaho. Univ. of Idaho Forest, Wildlife and Range Exp. Sta. Bull. 12. 44 p.

Merrill, E.H. 1978. Nutrient cycling in an ungulate vegetation complex, Selway River, Idaho. MS Thesis, Univ. of Idaho. $114 \mathrm{p}$.

Mueggler, W.F. and J.P. Blaisdell. 1958. Effects on associated species of burning, rotobeating, spraying and railing sagebrush. J. Range Manage. 11:61-66.

Nelson, J.R. 1974. Forest fire and big game in the Pacific Northwest. Proc. Tall Timbers Fire Ecol. Conf. 15: 85-102.

Pearson, H.A., J.A. Davis and G.H. Schuberb. 1972. Effects on wildfire on timber and forage production in Arizona. J. Range Manage. 25: 250-253.

Peek, J.M. and J.A. Keay. 1979. Fecal pH comparisons among three species of ungulates in Idaho. J. Wildl. Manage. 43: 796-798.

Ross, S., and C. Savage. 1967. Idaho earth science. Idaho Bur. of Mines and Geol., Earth Sci. Series 1. 271 p.

Schoenfeld, C.A., and J.C. Hendee. 1978. Wildlife Management in Wilderness. Boxwood Press, Pacific Grove, Calif. 172 p.

Stelfox, J.G. 1971. Bighorn sheep in the Canadian Rockies: A history 18001970. Canad. Field-Natur. 85:101-122.

Stelfox, J.G. 1976. Range ecology of Rocky Mountain bighorn sheep in Canadian national parks. Canad. Wildl. Serv. Rep. Ser. 39. 49 p. Wright, H.A., and J.O. Klemmedson. 1965. Effect of fire on bunchgrasses of the sagebrushgrass region in southern Idaho. Ecology 46:680-685.

\section{Dear Members and Subscribers:}

Big problem! We need your help. Journals are returned to the Denver office by the gross because we do not receive address changes. Journals are sent 2 nd class mail with return postage guaranteed and are not forwarded by the Post Office. Many times the Post Office does not even return the Journal(s), just the address label. Therefore, it costs us postage to send it, return it, and frequently we do not get the Journal back. Then when we get your change of address, it costs more money to mail another Journal to you. This problem costs an estimated $\$ 25.00$ per week, money which could be better spent on higher priority programs. And we receive irate correspondence and telephone calls because members do not receive their Journals. We are not responsible if you do not receive your Journals when you have not notified us of your new address.

Please! Send us your address changes! If you know you are moving but not sure where or when, we can hold your Journals in Denver until you settle in your new address. Please notify us at least one month before you move. 